\title{
Determining Effects of Freezing on Pasta Filata and Non-Pasta Filata Mozzarella Cheeses by Nuclear Magnetic Resonance Imaging
}

\author{
M.-I. Kuo, M. E. Anderson, ${ }^{1}$ and S. Gunasekaran \\ Department of Biological Systems Engineering, \\ 460 Henry Mall, \\ University of Wisconsin-Madison, Madison, WI 53706
}

\section{ABSTRACT}

The formation of ice during freezing of pasta filata and non-pasta filata Mozzarella cheeses, and the spatial redistribution of water $\mathrm{T}_{2}$ relaxation time and the changes of water self-diffusion coefficient (D) within the unfrozen and frozen-stored cheese samples were observed by nuclear magnetic resonance imaging. Images of water spin number density and water $\mathrm{T}_{2}$ relaxation time were obtained using spin-echo imaging pulse sequence. The water self-diffusion coefficient was measured by pulsed-field gradient spin-echo technique. The ice formation was accompanied by loss of signal intensity in the affected areas of the cheese sample. There was a significant change in $\mathrm{T}_{2}$ and $\mathrm{D}$ values of water following freezing-thawing, which can be used to characterize the effect of freezing on cheeses. The $\mathrm{D}$ values of the frozen-stored pasta filata Mozzarella cheese samples were higher than those for the unfrozen samples. Such a difference was not observed for the non-pasta filata Mozzarella cheese samples. The $\mathrm{T}_{2}$ distributions of frozen-stored pasta filata Mozzarella cheese samples were narrower, and those for the non-pasta filata Mozzarella cheese samples were broader $\mathrm{T}_{2}$. This may be attributed to the microstructure differences between the two cheeses.

(Key words: Mozzarella cheese, $\mathrm{T}_{2}$ relaxation, selfdiffusion coefficient, MRI)

\footnotetext{
Abbreviation key: FOV = field of view, LMPS = lowmoisture, part-skim, MRI = magnetic resonance imaging, $\mathbf{N M R}$ = nuclear magnetic resonance, $\mathbf{P G S E}=$ pulsed-field gradient spin-echo, SEM = scanning electron microscopy, $\mathbf{T E}=$ echo-delay time, $\mathbf{T R}=$ repetition time.

Received October 2, 2002.

Accepted February 27, 2003.

Corresponding author: S. Gunasekaran; e-mail: guna@wisc.edu.

${ }^{1}$ National Magnetic Resonance Facility at Madison (NMRFAM), Biochemistry Department, 433 Babcock Drive, University of Wisconsin-Madison, Madison, WI 53706.
}

\section{INTRODUCTION}

Freezing of block and shredded Mozzarella cheese soon after its manufacture is preferred to improve cheese production and handling. Although freezing is effective in extending the shelf-life and preserving the color, flavor, and nutritive value of many foods, freezing of cheeses presents problems. There have been several studies on frozen storage of Mozzarella cheese to ascertain if the cheese can be frozen, how long the frozen cheese can be stored, and what physical or textural changes result (Dahlstrom, 1978; Cervantes et al., 1983; Oberg et al., 1992; Diefes et al., 1993; Bertola et al., 1996). These studies indicate that freezing, thawing, and frozen storage modifies physical properties of Mozzarella cheese. Relatively few investigations into the effect of freezing on physicochemical characteristics and microstructure of cheese have been carried out (Fontecha et al., 1994, 1996; Perez-Munuera et al., 1999; Tejada et al., 2002), and those pertinent to Mozzarella cheese are scarce (Kuo, 2001; Kuo and Gunasekaran, 2003). It is believed that the changes in the physical states of water (i.e., characteristics of molecular motion of water or water mobility) and cheese microstructure after a freeze-thaw cycle influence cheese quality and functional properties (Kuo and Gunasekaran, 2003).

Nuclear magnetic resonance (NMR) and magnetic resonance imaging (MRI) can be used to detect freezing and thawing related changes in foods (Duce et al. 1992). The MRI is developed as a noninvasive and nondestructive method for routine use in medical research and diagnosis and has great potential for use in food science (Hills, 1995; Schmidt et al., 1996). Depending on the imaging protocol, we can obtain maps of spatial distribution of NMR parameters such as spin number density, spin-lattice relaxation time $\left(\mathrm{T}_{1}\right)$ and spin-spin $\left(\mathrm{T}_{2}\right)$ relaxation time, magnetization transfer rates, chemical shifts, self-diffusion coefficient (D), and velocity flow rates from a defined region within a large sample.

A number of reports have discussed the use of MRI to study changes following freezing of foods. Duce et al. 
(1992) investigated the effect of freezing on courgette using MRI. They found qualitative changes in images of courgette before and after freezing and thawing. Freezing ruptured the cell walls and altered the tissue morphology, which in turn affected the transverse relaxation time of water protons in the tissue, and thus the image contrast. Gamble (1994) used MRI to study the distribution of water and sugar in blueberries and changes in relaxation times before and after freezing/ thawing. Kerr et al. (1997) investigated whether freeze damage of kiwifruit could be detected and related to changes in various properties measured by NMR (i.e., changes in NMR relaxation parameters and diffusion of water molecules). The $\mathrm{T}_{2}$ relaxation of water was faster, and the water self-diffusion coefficient was greater in frozen-thawed fruit than in fresh fruit. They explained that water is no longer confined to the fruit cell after cell dehydration and rupture by freezing and thawing, thus the effect of cell relaxation is diminished, and the water diffusion is more rapid in the freeze-thawed samples. They concluded that the significant changes in $\mathrm{T}_{2}$ relaxation and diffusion properties following freezing has implications for designs for online sensors assessing fruit quality.

In recent years, MRI techniques have been applied to characterize the freezing process (Kerr et al., 1996, 1997, 1998). Advances in MRI have made it possible to view phase transitions in vivo (McCarthy and Kouten, 1990; McCarthy, 1994). Loss of proton mobility during phase transitions results in a decrease in signal intensity, i.e., a decrease in signal intensity for water within a given volume element during freezing is indicative of transition from liquid to solid state. It is desirable to observe food freezing noninvasively and in real time. Visualizing ice formation would allow monitoring the freezing rate and determining when freezing is complete.

Our objectives were to use MRI and NMR to: 1) follow formation of ice in pasta filata and non-pasta filata Mozzarella cheeses during freezing by mapping the distribution of water and 2) study the effect of freezing on structure and mobility of water in pasta filata and non-pasta filata Mozzarella cheeses through observed changes in $\mathrm{T}_{2}$ relaxation time and self-diffusion coefficient of water molecules.

\section{MATERIALS AND METHODS}

\section{Cheese Making and Experimental Protocol}

Low-moisture, part-skim (LMPS) pasta filata and non-pasta filata Mozzarella cheeses were manufactured in the Wisconsin Center for Dairy Research pilot plant at University of Wisconsin-Madison. The make procedures for the cheeses and the methods of their

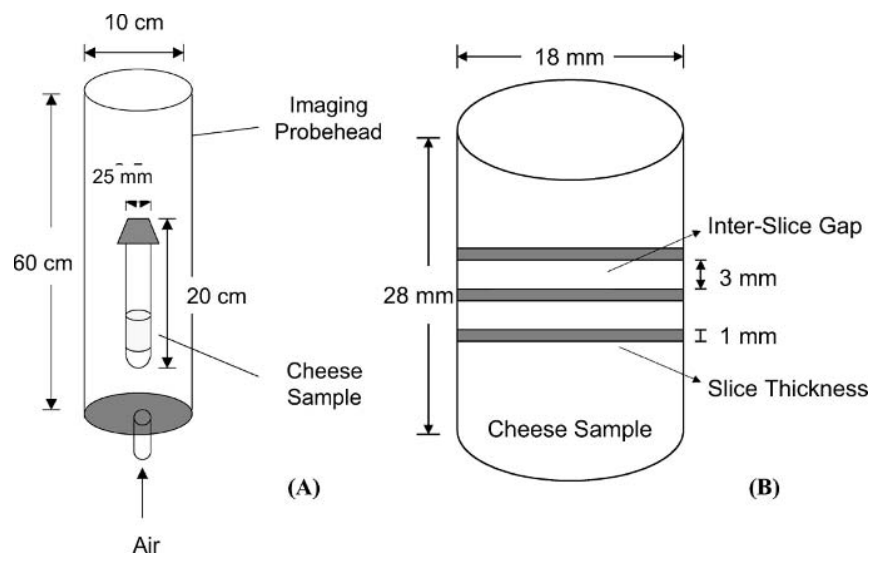

Figure 1. The arrangement of the cheese sample in the imaging probehead (A) and illustration of slice thickness and inter-slice gap in the MRI imaging of the cheese sample (B).

composition analysis were described in Kuo et al. (2001). All composition analyses were done in duplicate.

Eight loaves (each about $2.5 \mathrm{~kg}$ ) of cheese from a single batch were cut into $5-\times 10-\times 7$-cm blocks and vacuum sealed in plastic cheese packaging bags (VF400, Vilutis \& Co. Inc., Frankfort, IL). Forty-five cheese blocks were randomly divided into three equal groups and stored at $5^{\circ} \mathrm{C}$ until the freezing tests. Each of the three groups was taken at 2, 7, and $14 \mathrm{~d}$ after manufacture and was frozen and stored at $-21.5^{\circ} \mathrm{C}$ in a laboratory freezer. The blocks of cheese from each group were removed from the freezer after 1 and $4 \mathrm{wk}$, and then thawed at $5^{\circ} \mathrm{C}$. Thawed cheese blocks were tempered in the refrigerator at $5^{\circ} \mathrm{C}$ for 1,7 , and $14 \mathrm{~d}$.

\section{Imaging Techniques}

A Bruker Instruments DMX-400 Avance console connected to a 9.4-T, 89-mm bore magnet (Bruker, Billerica, MA) available at the National Magnetic Resonance Facility at Madison at the University of Wisconsin-Madison was used for mapping the $\mathrm{T}_{2}$ of the cheese samples. Because of the size limitations associated with the MRI system, cheese samples of $18-\mathrm{mm}$ diameter $\times 28-\mathrm{mm}$ height were used. The multislice MRI micro-images of cheese samples were acquired with a $25-\mathrm{mm}$ NMR tube in a $25-\mathrm{mm}$ probe. Figure $1 \mathrm{~A}$ shows the arrangement of a cheese sample in the MRI system.

The spin-echo imaging pulse sequence, shown in Figure 2 , was used to acquire $\mathrm{T}_{2}$-weighted images at the axial section with a slice thickness of $1 \mathrm{~mm}$, an inplane resolution of $0.098 \mathrm{~mm} \times 0.098 \mathrm{~mm}$, and a field of view (FOV) of $25 \mathrm{~mm}$. Four $\mathrm{T}_{2}$-weighted images 


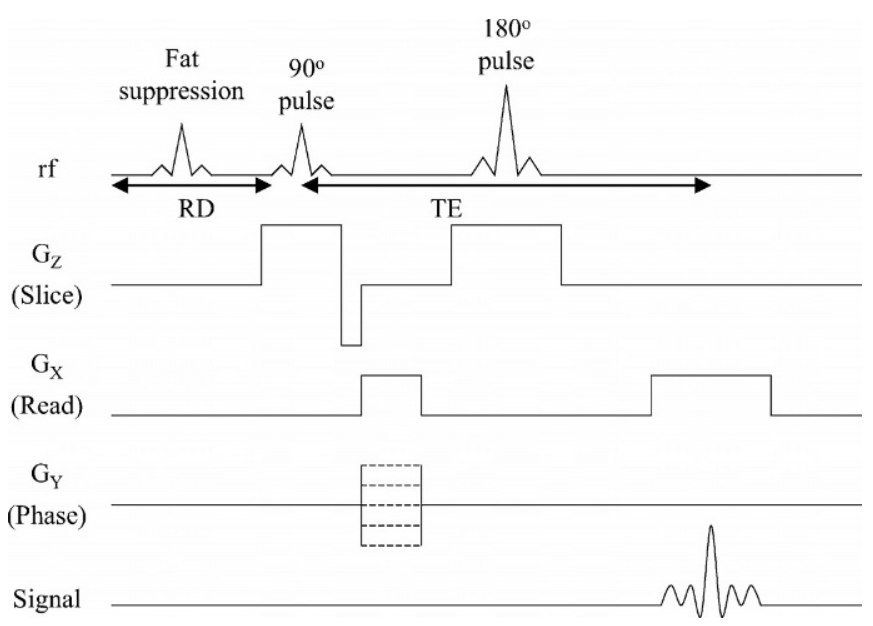

Figure 2. The spin-echo imaging sequence. $\mathrm{RD}=$ relaxation delay; $\mathrm{TE}=$ echo-delay time; $\mathrm{G}_{\text {read }}=$ frequency encoding gradient; $\mathrm{G}_{\text {phase }}=$ phase encoding gradient; $\mathrm{G}_{\text {slice }}=$ slice selective gradient; $\mathrm{rf}=$ radio frequency pulse.

with echo-delay times (TE) of $6,9,12$, and $15 \mathrm{~ms}$ and a repetition time (TR) of $3 \mathrm{~s}$ were acquired. The total imaging time for the four acquisitions was $2 \mathrm{~h}$. Each dataset consisted of 256 time domain points by 256 phase encoding steps. The multislice images with 3mm interslice gap were taken by simultaneously sectioning a cheese sample and used as replicates (Figure 1B). Three slices were acquired for each cheese sample. Temperature was maintained at $5^{\circ} \mathrm{C}$.

The data for the same pixel location at different $\mathrm{TE}$ in each image were fitted to a single exponential decay model (equation 1):

$$
M=M_{0} \exp \left(-\frac{T E}{T_{2}}\right)
$$

where $\mathrm{M}$ is the observed transverse magnetization, $\mathrm{M}_{0}$ is the equilibrium magnetization (proportional to liquid proton density), and $\mathrm{T}_{2}$ is the transverse relaxation time. Fitting these data provides maps of the distribution of $\mathrm{T}_{2}$ and $\mathrm{M}_{0}$ values. A linear regression program for the $\mathrm{T}_{2}$ data fitting was developed. The MRI data acquired from the imaging system were processed, fitted, and plotted using MATLAB mathematics software (Version 5.3, MathWorks, Inc., Natick, MA).

\section{Magnetic Resonance Imaging During Freezing}

To observe the freezing process in situ, the cold air $\left(-40^{\circ} \mathrm{C}\right)$ was directed past the sample tube and the long axis of sample was held parallel with the flowing air direction (Figure 1A). Images of cheese sample

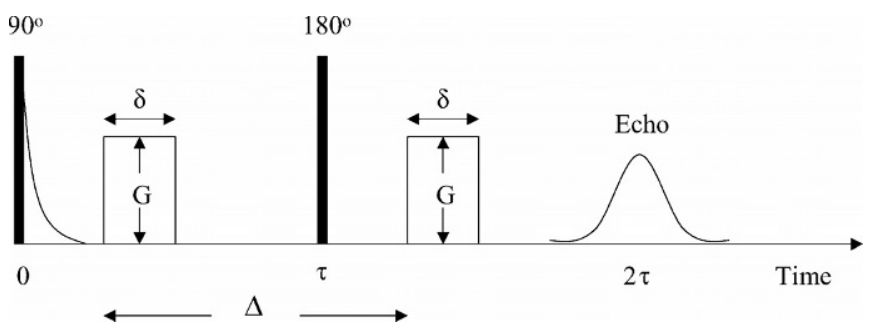

Figure 3. The basic pulsed-field gradient NMR self-diffusion experiment. $\Delta$ denotes the time between a pair of pulsed field gradients of duration $\delta$ and magnitude G. $\tau$ denotes the time between two RF pulses.

were acquired on both axial and transverse sections with a $128 \times 128$ pixels matrix, 3 -mm slice thickness, and $0.195-\mathrm{mm}$ per pixel in-plane resolution at successive time intervals. A spin-echo imaging pulse sequence was used to give minimum imaging time; TE was $6 \mathrm{~ms}$, while TR was $1 \mathrm{~s}$. The total acquisition time was 2 min.

\section{Water Self-Diffusion Coefficient (D) Measurements}

The water self-diffusion coefficient (D) measurements were done in duplicate at $5^{\circ} \mathrm{C}$ using the pulsedfield gradient spin-echo (PGSE) technique (Figure 3). The $\mathrm{D}$ value $\left(\mathrm{m}^{2} \cdot \mathrm{s}^{-1}\right)$ was calculated by fitting the data to the following equation (Stejskal and Tanner, 1965):

$$
I(2 \tau) / I(0)=\exp (-k D)
$$

where $I(2 \tau)$ and $I(0)$ are the echo signal in the presence and absence of the pulsed gradient (i.e., the echo attenuation), respectively; $\tau$ is the time between the two RF pulses; $\mathrm{D}$ is the self-diffusion coefficient of the nuclear spins along the gradient direction. $k$ is equal to $(\gamma G \delta)^{2}(\Delta-\delta / 3)$ where $\gamma$ is the nuclear gyromagnetic ratio; $\delta$ is the gradient pulse duration; $\mathrm{G}$ is the gradient amplitude; and $\Delta$ is the time separation of the two gradient pulses. The intensities of the echoes $(I)$ at a fixed diffusion time were measured, and the $\ln [I(2 \tau) /$ $I(0)]$ was plotted against $k$. This yielded a straight line with a slope $-\mathrm{D}$. For our experimental conditions, G was $0.226 \mathrm{~T} / \mathrm{m}, \Delta$ was $8 \mathrm{~ms}$, and $\delta$ varied between 0.52 and $7.27 \mathrm{~ms}$. Linear curve fitting was done using SPLUS software (version 3.2, MathSoft Inc., Seattle, WA).

The pulsed gradient was applied both along and across the protein fibers in pasta filata Mozzarella cheese samples, while no specific consideration was given for the non-pasta filata Mozzarella cheese samples. 

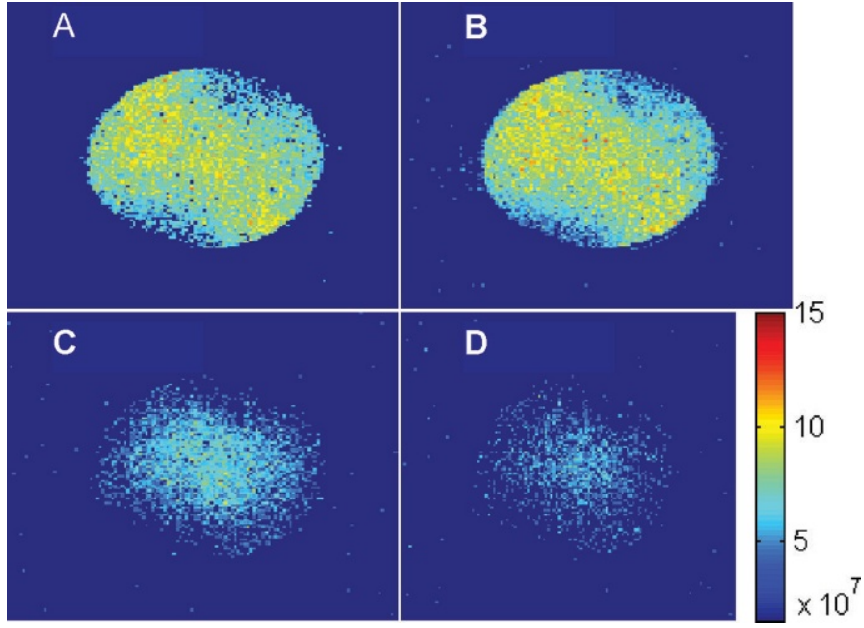

Figure 4. Magnetic resonance images (resolution $=0.195 \mathrm{~mm}$ ) acquired on axial section during freezing of pasta filata Mozzarella. Freezing temperature $=-40^{\circ} \mathrm{C}$, air speed $=10^{-2} \mathrm{~m}^{3} / \mathrm{h}$. A $=0 \mathrm{~min} ; \mathrm{B}$ $=15 \mathrm{~min} ; \mathrm{C}=37 \mathrm{~min} ; \mathrm{D}=50 \mathrm{~min}$. The color scale of the images is proportional to the proton signal intensity.

\section{RESULTS AND DISCUSSION}

\section{Cheese Composition}

The composition of the pasta filata Mozzarella cheese was: $46.95 \pm 1.05 \%$ moisture, $21.75 \pm 1.14 \%$ fat, $1.32 \pm 0.30 \%$ salt, $24.87 \pm 0.91 \%$ protein, with a $\mathrm{pH}$ of $5.16 \pm 0.01$; and that of non-pasta filata Mozzarella cheese was: $46.74 \pm 1.10 \%$ moisture, $22.91 \pm 1.21 \%$ fat, $1.88 \pm 0.22 \%$ salt, $24.56 \pm 1.10 \%$ protein, with a $\mathrm{pH}$ of $5.24 \pm 0.01$.

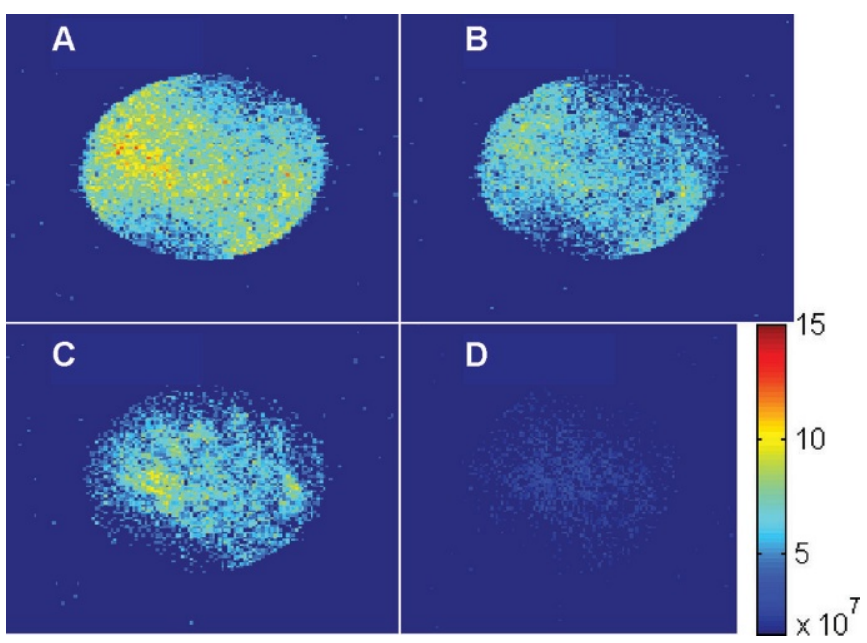

Figure 5. Magnetic resonance images (resolution $=0.195 \mathrm{~mm}$ ) acquired on axial section during freezing of non-pasta filata Mozzarella. Freezing temperature $=-40^{\circ} \mathrm{C}$, air speed $=10^{-2} \mathrm{~m}^{3} / \mathrm{h} . \mathrm{A}=0$ $\min ; \mathrm{B}=11 \mathrm{~min} ; \mathrm{C}=26 \mathrm{~min} ; \mathrm{D}=38 \mathrm{~min}$. The color scale of the images is proportional to the proton signal intensity.

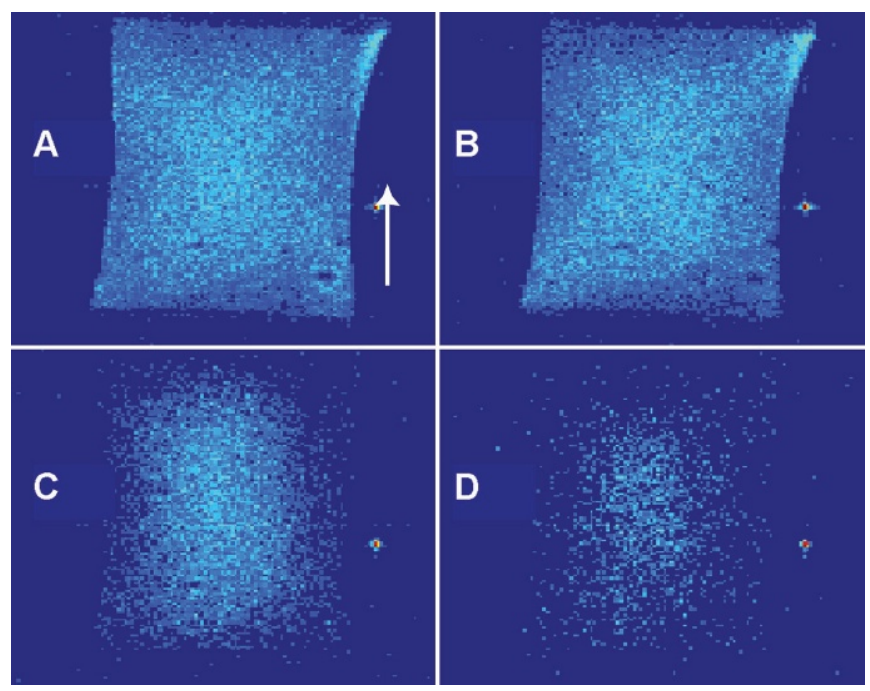

Figure 6. Magnetic resonance images (resolution $=0.195 \mathrm{~mm}$ ) acquired on transverse section during freezing of pasta filata Mozzarella (arrow represents the direction of air flow). Freezing temperature $=-40^{\circ} \mathrm{C}$, air flow $=10 \mathrm{~L} / \mathrm{h} . \mathrm{A}=0 \mathrm{~min} ; \mathrm{B}=15 \mathrm{~min} ; \mathrm{C}=29 \mathrm{~min}$; $\mathrm{D}=41 \mathrm{~min}$

\section{Images During Freezing}

MRI images of pasta filata and non-pasta filata Mozzarella cheese samples acquired on axial section during freezing are presented in Figures 4 and 5, respectively. Red-yellow regions of the image correspond to higher signal intensity and thus can be associated with greater density of liquid water or regions with larger
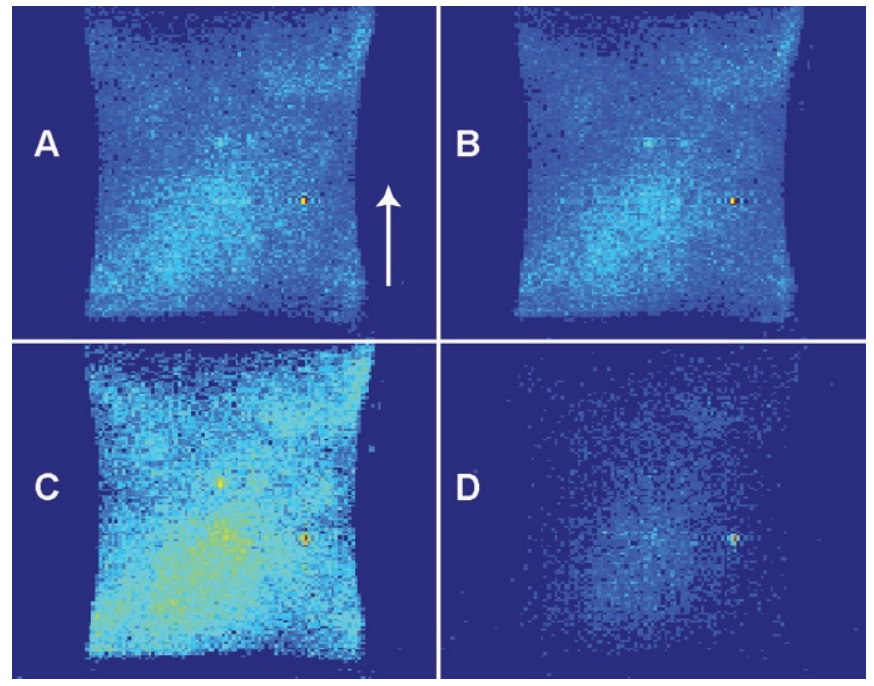

Figure 7. Magnetic resonance images (resolution $=0.195 \mathrm{~mm}$ ) acquired on transverse section during freezing of non-pasta filata Mozzarella (arrow represents the direction of air flow). Freezing temperature $=-40^{\circ} \mathrm{C}$, air flow $=10 \mathrm{~L} / \mathrm{h} . \mathrm{A}=0 \mathrm{~min} ; \mathrm{B}=12 \mathrm{~min} ; \mathrm{C}=21$ $\min ; \mathrm{D}=32 \mathrm{~min}$. 
Table 1. Effect of frozen storage at $-21.5^{\circ} \mathrm{C}$ and tempering at $5^{\circ} \mathrm{C}$ on water self-diffusion coefficient (D) of pasta filata Mozzarella (The pulsed gradient was applied along the protein fibers in cheese specimens).

\begin{tabular}{llcc}
\hline & \multicolumn{3}{c}{ Aging period before frozen storage } \\
\cline { 2 - 4 } Treatments & $2 \mathrm{~d}$ & $7 \mathrm{~d}$ & $14 \mathrm{~d}$ \\
\cline { 2 - 4 } & & $\mathrm{D}\left(\mathrm{m}^{2} \mathrm{~s}^{-1}\right) \times 10^{-10}$ & $4.03^{\mathrm{d}}$ \\
Unfrozen & $4.23^{\mathrm{d}}$ & $4.38^{\mathrm{a}}$ & \\
1 wk Frozen storage & & $4.58^{\mathrm{ab}}$ \\
Temper 1 d & $4.56^{\mathrm{ab}}$ & $4.17^{\mathrm{b}}$ & $4.61^{\mathrm{ab}}$ \\
Temper 7 d & $4.44^{\mathrm{bc}}$ & $3.89^{\mathrm{c}}$ & $4.15^{\mathrm{cd}}$ \\
Temper 14 d & $4.37^{\mathrm{cd}}$ & $3.93^{\mathrm{c}}$ & $4.73^{\mathrm{a}}$ \\
4 wk Frozen storage & & $4.62^{\mathrm{ab}}$ \\
Temper 1 d & $4.56^{\mathrm{ab}}$ & $4.36^{\mathrm{a}}$ & $4.38^{\mathrm{bc}}$ \\
Temper 7 d & $4.72^{\mathrm{a}}$ & $4.15^{\mathrm{b}}$ & $4.26^{\mathrm{a}}$ \\
Temper 14 d & $4.53^{\mathrm{bc}}$ & &
\end{tabular}

$\mathrm{T}_{2}$ relaxation time. As ice is formed in the sample, a substantial decrease in signal intensity was seen and the image pixels became dark blue.

The changes in water distribution in cheese during freezing are obvious. Ice formation begins from the outer regions of the cheese sample and progresses toward the interior (Figures $4 \mathrm{C}$ and $5 \mathrm{C}$ ). As can be seen, the images show fairly symmetric freezing about the central axis. After approximately $50 \mathrm{~min}$ in pasta filata Mozzarella cheese sample (Figure 4D) and $38 \mathrm{~min}$ in non-pasta filata Mozzarella cheese sample (Figure 5D), the signal intensity was minimal throughout cheese sample.

The images of pasta filata and non-pasta filata Mozzarella cheese samples acquired on transverse section at selected times during freezing are shown in Figures 6 and 7, respectively. As can be seen from the horizontal view, freezing was symmetrical as well. Images of freezing pasta filata and non-pasta filata Mozzarella cheese samples showed a continuously advancing icewater interface.

The results from Figures 4, 5, 6, and 7 indicate that MRI can be used to monitor the development of ice during cheese freezing in real time. Formation of ice in cheese might be affected by its geometry and composition, as well as the heat transfer characteristics of the environment, and the presence of ice-nucleating agents (Kerr et al., 1997). The rate of advance of the ice-water interface in the sample during freezing is governed by the air-flow conditions. When air flow was directed across the sample, as expected, those regions most directly exposed to cold air froze more rapidly (Figures 6C and 7D). Our results are in agreement with the findings of Kerr et al. (1997, 1998).

\section{Changes in Water Self-Diffusion Coefficient After Freezing-Thawing}

Effects of frozen storage and tempering on water self-diffusion coefficient (D) of pasta filata Mozzarella are given in Tables 1 and 2 . The $\mathrm{D}$ values reported are bulk measurements. Due to the limitations of extra MRI hardware required generating strong diffusion gradients a spatial D-map was not acquired. The selfdiffusion coefficient measures the translational mobility of water. Thus, direct and more detailed information on dynamic properties of water can be obtained by measuring the molecular level self-diffusion coefficient.

Table 1 represents the results when the pulsed gradient in PGSE technique was along the protein fibers of pasta filata Mozzarella cheese sample, whereas Table 2 represents the results when the gradient was across the protein fibers. The $\mathrm{D}$ values of unfrozen cheese samples when the gradient was along the protein fibers $\left(4.03 \times 10^{-10}\right.$ to $\left.4.23 \times 10^{-10} \mathrm{~m}^{2} \cdot \mathrm{s}^{-1}\right)$ were significantly $(P<0.05)$ higher than that of the sample taken across the protein fibers $\left(3.44 \times 10^{-10}\right.$ to $3.72 \times$ $10^{-10} \mathrm{~m}^{2} \cdot \mathrm{s}^{-1}$ ). Generally, D values of frozen-stored pasta filata Mozzarella cheese samples tempered $1 \mathrm{~d}$ were significantly $(P<0.05)$ higher than those for the unfrozen samples. However, during tempering, changes in D values of frozen-stored pasta filata Mozzarella cheese samples did not follow a trend.

Effects of frozen storage and tempering on $\mathrm{D}$ values of non-pasta filata Mozzarella are given in Table 3. The differences between the $\mathrm{D}$ values of unfrozen nonpasta filata Mozzarella cheese samples and that of frozen-stored samples tempered $1 \mathrm{~d}$ were not statistically significant $(P>0.05)$. Generally, D values de- 
Table 2. Effect of frozen storage at $-21.5^{\circ} \mathrm{C}$ and tempering at $5^{\circ} \mathrm{C}$ on water self-diffusion coefficient (D) of pasta filata Mozzarella (The pulsed gradient was applied across the protein fibers in cheese specimens).

\begin{tabular}{llcc}
\hline & \multicolumn{3}{c}{ Aging period before frozen storage } \\
\cline { 2 - 4 } Treatments & $2 \mathrm{~d}$ & $7 \mathrm{~d}$ & $14 \mathrm{~d}$ \\
\cline { 2 - 4 } & $3.72^{\mathrm{b}}$ & $\mathrm{D}\left(\mathrm{m}^{2} \cdot \mathrm{s}^{-1}\right) \times 10^{-10}$ & $3.44^{\mathrm{d}}$ \\
Unfrozen & & $3.47^{\mathrm{c}}$ & \\
1 wk Frozen storage & & $3.43^{\mathrm{d}}$ \\
Temper 1 d & $3.97^{\mathrm{a}}$ & $4.13^{\mathrm{b}}$ & $4.23^{\mathrm{ab}}$ \\
Temper 7 d & $3.86^{\mathrm{ab}}$ & $4.07^{\mathrm{b}}$ & $3.94^{\mathrm{b}}$ \\
Temper 14 d & $3.79^{\mathrm{b}}$ & $3.63^{\mathrm{c}}$ & $3.77^{\mathrm{c}}$ \\
4 wk Frozen storage & & $4.45^{\mathrm{a}}$ \\
Temper 1 d & $4.06^{\mathrm{a}}$ & $4.34^{\mathrm{ab}}$ & $4.17^{\mathrm{ab}}$ \\
Temper 7 d & $4.01^{\mathrm{a}}$ & $4.27^{\mathrm{ab}}$ & \\
Temper 14 d & $3.68^{\mathrm{b}}$ & &
\end{tabular}

creased as the frozen-stored non-pasta filata Mozzarella cheese samples tempered from 1 to $7 \mathrm{~d}$, but no significant differences were observed as the cheese samples tempered from 7 to $14 \mathrm{~d}$.

Kuo (2001) observed damaged protein matrix in frozen-stored pasta filata and non-pasta filata Mozzarella cheeses by scanning electron microscopy (SEM). This might be attributed to the local dehydration of proteins and ice recrystallization during freezing and frozen storage (Diefes et al., 1993). Water tends to separate from the protein as a result of freezing and thawing (Webb and Arbuckle, 1977). Upon tempering, the proteins are unable to fully rebind water (Diefes et al., 1993). Thus, water is less confined to the protein matrix, as evidenced by a significant increase in water self-diffusion coefficient of frozen-stored pasta filata Mozzarella cheese sample with respect to the unfrozen sample (Tables 1 and 2).

There is no significant difference between the $\mathrm{D}$ values of frozen-stored non-pasta filata Mozzarella cheese samples tempered for $1 \mathrm{~d}$ and that of unfrozen samples. This might be due to the sampling of the water selfdiffusion coefficient measurements. The frozen-stored non-pasta filata Mozzarella cheese sample used for self-diffusion coefficient measurement were cut at noncrumbly (undamaged) region. Thus, changes in the D value of undamaged region (from macroscopic viewpoint) of non-pasta filata Mozzarella cheese sample might be insignificant compared with unfrozen sample. The effects of frozen storage on the $D$ values of pasta filata and non-pasta filata Mozzarella cheese samples were the same regardless of the duration of frozen storage.

\section{Changes in $\mathrm{T}_{2}$ Relaxation After Freezing-Thawing Pasta Filata Mozzarella}

A $\mathrm{T}_{2}$-map of the non-pasta filata Mozzarella cheese sample is shown in Figure 8. In this figure, the intensity of each pixel is directly related to the $\mathrm{T}_{2}$ value.

Table 3. Effect of frozen storage at $-21.5^{\circ} \mathrm{C}$ and tempering at $5^{\circ} \mathrm{C}$ on water self-diffusion coefficients (D) of non-pasta filata Mozzarella.

\begin{tabular}{llcc}
\hline & \multicolumn{3}{c}{ Aging period before frozen storage } \\
\cline { 2 - 4 } Treatments & $2 \mathrm{~d}$ & $7 \mathrm{~d}$ & $14 \mathrm{~d}$ \\
\cline { 2 - 4 } & $3.75^{\mathrm{ab}}$ & $\mathrm{D}\left(\mathrm{m}^{2} \cdot \mathrm{s}^{-1}\right) \times 10^{-10}$ & $4.26^{\mathrm{a}}$ \\
Unfrozen & & $3.63^{\mathrm{ab}}$ & \\
1 wk Frozen storage & $3.85^{\mathrm{a}}$ & $3.42^{\mathrm{b}}$ & $4.21^{\mathrm{a}}$ \\
Temper 1 d & $3.52^{\mathrm{b}}$ & $3.19^{\mathrm{c}}$ & $3.90^{\mathrm{b}}$ \\
Temper 7 d & $3.87^{\mathrm{a}}$ & $3.53^{\mathrm{ab}}$ & $3.96^{\mathrm{b}}$ \\
Temper 14 d & & & $4.28^{\mathrm{a}}$ \\
4 wk Frozen storage & $3.93^{\mathrm{a}}$ & $3.75^{\mathrm{a}}$ & $3.61^{\mathrm{bc}}$ \\
Temper 1 d & $3.40^{\mathrm{bc}}$ & $3.66^{\mathrm{ab}}$ & $3.92^{\mathrm{b}}$ \\
Temper 7 d & $3.60^{\mathrm{b}}$ & $3.79^{\mathrm{a}}$ & \\
Temper 14 d & & &
\end{tabular}

${ }^{\mathrm{a}, \mathrm{b}}$ Different letters indicate significant difference $(P<0.05)$ between the mean values within each aging period before frozen storage. 

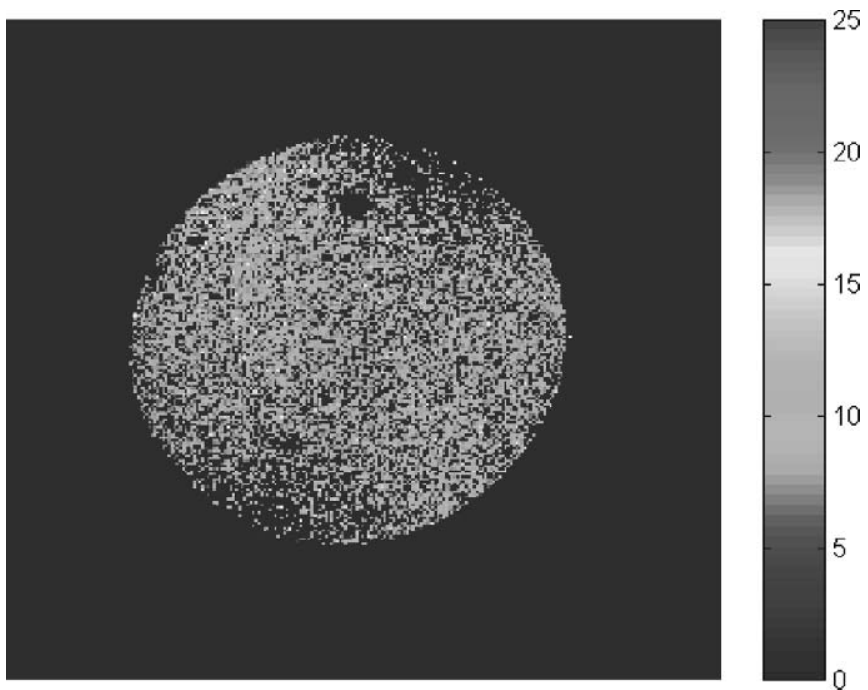

Figure 8. Magnetic resonance image of $\mathrm{T}_{2}$ of non-pasta filata Mozzarella (resolution $=0.098 \mathrm{~mm}$ ). For color, please see online version, in which the scale represents $\mathrm{T}_{2}$ value.

Changes in the distribution of $\mathrm{T}_{2}$ values of pasta filata Mozzarella after freezing-thawing are illustrated by $\mathrm{T}_{2}$ histograms (Figures 9 and 10). The histograms were obtained by counting the number of pixels with a certain range of $\mathrm{T}_{2}$ values within the image of a cheese sample and then normalizing it by dividing the total number of pixels. Changes in the distribution of $\mathrm{T}_{2}$ values among three slices of one cheese sample were indistinguishable during the entire study. Thus, the $\mathrm{T}_{2}$ histograms presented in this study represent the changes in the middle slice of the cheese sample.

The histogram distributions of the $\mathrm{T}_{2}$ values of pasta filata Mozzarella cheese stored frozen at $2 \mathrm{~d}$ postmanufacture are shown in Figure 9. The peak value of $\mathrm{T}_{2}$ for unfrozen cheese sample was $50 \mathrm{~ms}$ (Figure 9A) compared with the value of $10 \mathrm{~ms}$ for the samples tempered for $1 \mathrm{~d}$ after 1 - and 4 -wk frozen storage (Figures $9 \mathrm{~B}$ and $9 \mathrm{E}$ ). The distribution of $\mathrm{T}_{2}$ values in unfrozen cheese sample was broad, but the distribution became narrow after the sample was stored frozen. That is, $\mathrm{T}_{2}$ values were more uniform across the sample in both 1- and 4-wk frozen-stored samples tempered for $1 \mathrm{~d}$ as compared to unfrozen samples. The distribution of $T_{2}$ values in 1-wk frozen-stored cheese sample became broader after it was tempered for $7 \mathrm{~d}$ (Figure 9C) with respect to the sample tempered for $1 \mathrm{~d}$ (Figure 9B). However, the $\mathrm{T}_{2}$ distribution of the 1 -wk frozen-stored cheese sample tempered for $14 \mathrm{~d}$ (Figure 9D) was very similar to the frozen-stored sample tempered for $1 \mathrm{~d}$. As the 4-wk frozen-stored cheese sample was tempered for 7 and $14 \mathrm{~d}$, the $\mathrm{T}_{2}$ values became progressively less uniform. The distributions
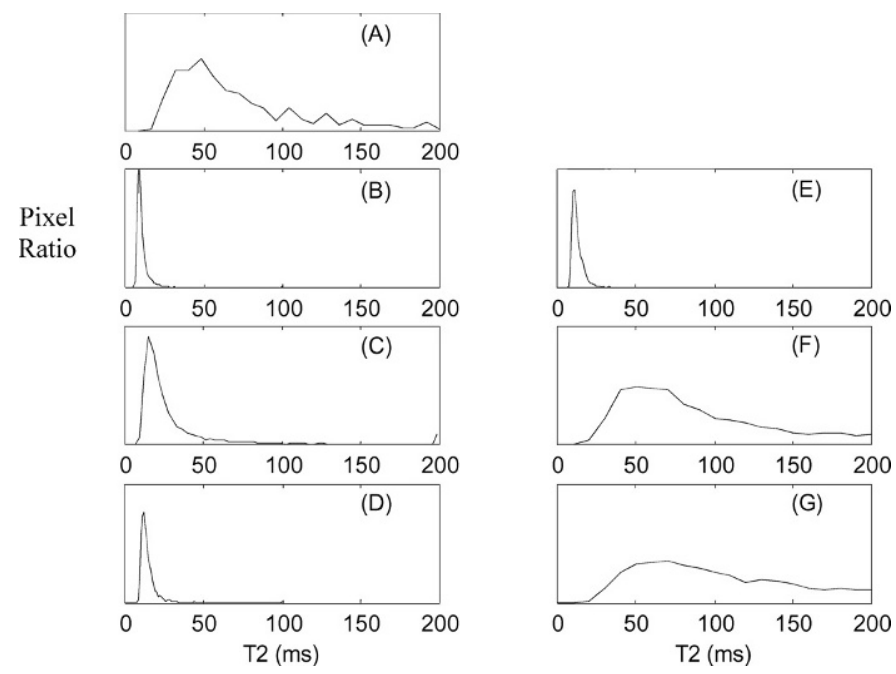

Figure 9. Histogram distribution of $\mathrm{T}_{2}$ relaxation time in pasta filata Mozzarella cheese unfrozen (A) and frozen $2 \mathrm{~d}$ postmanufacture then thawed after $1 \mathrm{wk}$ and tempered for 1 (B), 7 (C), and $14 \mathrm{~d}$ (D); thawed after $4 \mathrm{wk}$ and tempered for $1(\mathrm{E}), 7(\mathrm{~F})$, and $14 \mathrm{~d}(\mathrm{G})$. Pixel ratio on $\mathrm{Y}$-axis is the number of pixels of a certain range of $\mathrm{T}_{2}$ values divided by total number of pixels in the image.

of $\mathrm{T}_{2}$ values broadened markedly over the tempering period, as illustrated by the histogram of $\mathrm{T}_{2}$ values in Figures $9 \mathrm{~F}$ and $9 \mathrm{G}$. The peak of $\mathrm{T}_{2}$ shifted to $55 \mathrm{~ms}$ for frozen-stored cheese sample tempered for $7 \mathrm{~d}$ and further to $63 \mathrm{~ms}$ for sample tempered $14 \mathrm{~d}$.

Figure 10 shows the histogram distribution of $\mathrm{T}_{2}$ of pasta filata Mozzarella cheese stored frozen at $7 \mathrm{~d}$
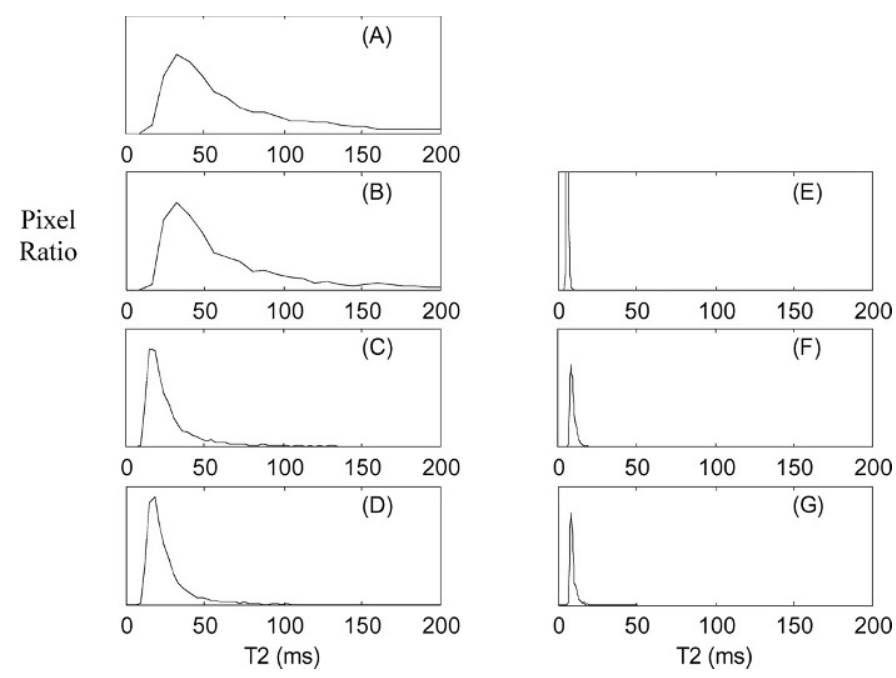

Figure 10. Histogram distribution of $\mathrm{T}_{2}$ relaxation time in pasta filata Mozzarella cheese unfrozen $(\mathrm{A})$ and frozen $7 \mathrm{~d}$ postmanufacture then thawed after $1 \mathrm{wk}$ and tempered for 1 (B), 7 (C), and $14 \mathrm{~d}(\mathrm{D})$; thawed after $4 \mathrm{wk}$ and tempered for $1(\mathrm{E}), 7$ (F), and $14 \mathrm{~d}(\mathrm{G})$. Pixel ratio on $\mathrm{Y}$-axis is the number of pixels of a certain range of $\mathrm{T}_{2}$ values divided by total number of pixels in the image. 
postmanufacture. The 1-wk frozen-stored cheese sample tempered for $1 \mathrm{~d}$ (Figure 10B) has a $\mathrm{T}_{2}$ distribution similar in general appearance to that of the unfrozen sample (Figure 10A). As the 1-wk frozen-stored cheese sample was tempered for 7 and $14 \mathrm{~d}$, the peak shifted to a lower $\mathrm{T}_{2}$ value (Figures $10 \mathrm{C}$ and $10 \mathrm{D}$ ), and the $\mathrm{T}_{2}$ distribution became narrower. Further frozen storage of the cheese sample to $4 \mathrm{wk}$ showed a narrowing of the $\mathrm{T}_{2}$ distribution around the value of $6 \mathrm{~ms}$ (Figure $10 \mathrm{E})$. Tempering the 4 -wk frozen-stored cheese sample for 7 and $14 \mathrm{~d}$ produced only a small shift in the $\mathrm{T}_{2}$ distribution with the peak moving to $8 \mathrm{~ms}$ (Figures $10 \mathrm{~F}$ and $10 \mathrm{G}$ ). The results of cheese sample stored frozen at $14 \mathrm{~d}$ post-manufacture were not available due to the low signal intensity in the images of cheese samples and several missing data.

There was a significant change in the $\mathrm{T}_{2}$ distribution following freezing, frozen storage, and thawing, which can be used to characterize the freezing effect on pasta filata Mozzarella cheese. In general, the frozen-stored pasta filata Mozzarella cheese samples tempered for $1 \mathrm{~d}$ have a narrower $\mathrm{T}_{2}$ distribution compared with those of unfrozen samples and with all relaxation times shifted to shorter values (Figure 9B, 9E, and $10 \mathrm{E})$. An exception was found in 1-wk frozen-stored pasta filata Mozzarella cheese sample tempered for 1 $\mathrm{d}$ that stored frozen at $7 \mathrm{~d}$ postmanufacture (Figure 10B).

Changes in the $\mathrm{T}_{2}$ relaxation time after freezing and thawing were also found in several food systems (Duce et al, 1992; Gamble, 1994; Rutledge et al., 1994; Kerr et al., 1997). Duce et al. (1992) showed that the overall intensity of the image of the frozen courgette is greater than that of the fresh courgette. A relative image contrast between different types of tissue is less distinct in the frozen sample due to altering morphology of the tissue during freezing and thawing. Gamble (1994) observed an increase in $\mathrm{T}_{2}$ following freezing in blueberries as a result of the rupture of water retaining cell walls.

Rutledge et al. (1994) observed that the completely thawed potato sample has a $\mathrm{T}_{2}$ relaxation time distribution similar in general appearance to that of unfrozen sample at the same temperature but with all relaxation times shifted to shorter values. They concluded that the shift of $\mathrm{T}_{2}$ to shorter relaxation times after a freeze-thaw cycle results from ice crystal damage and the resulting enzymatic degradation of macromolecules. Kerr et al. (1997) reported that the average $\mathrm{T}_{2}$ for thawed kiwifruit was significantly $(P<0.01)$ shorter than that of fresh fruit. However, the diffusion was more rapid in freeze-thawed samples. They suspected that relaxation might be affected by the presence of relaxation sinks at the surface. These relax- ation sinks can normally be attributed to paramagnetic impurities at the surface of hindrance in molecular tumbling near the surface (Chui et al., 1995).

Changes in $\mathrm{T}_{2}$ relaxation time were also found between firm and bruised apple tissue (McCarthy et al., 1995). The authors showed that the bruised tissue regions of apple appeared brighter than firm tissue in NMR images, and measured a decreased in $\mathrm{T}_{2}$ in bruised regions of apple using CPMG pulse sequence. By comparing spin-echo images with gradient-recalled-echo images, they proved that the contrast was attributable to a change in diamagnetic susceptibility as a result of the partial destruction of the cellular structure caused by bruising. However, no discussion on the changes of $\mathrm{T}_{2}$ was given in their study.

Structural damage of foods by freezing or bruising alters the $\mathrm{T}_{2}$ value. However, the difference between $\mathrm{T}_{2}$ relaxation time of frozen-stored and unfrozen samples was not the same in different food systems because of the differences in the microstructure. The specific causes contributing to the change in $\mathrm{T}_{2}$ relaxation time following freezing reported in the literature were not elucidated.

The water $\mathrm{T}_{2}$ relaxation of pasta filata Mozzarella cheese sample might depend on the combinations of several possible factors among which are nonhomogeneity of the external magnetic field; mobility of the water molecules; nonhomogeneity of the local magnetic field due to variation in the magnetic susceptibility within the sample, and chemical exchange between different sites of different mobility (for example, protons of more mobile water molecules exchange with protons of less mobile protein molecules). The abrupt change in the magnetic susceptibility at the boundaries between water and fiber surface generate the local magnetic field gradients (Gasel and Lee, 1974; Callaghan, 1990). The variation of magnetic susceptibility at the boundaries of small water pockets are large; thus, increase the local magnetic field gradient resulting in a short $\mathrm{T}_{2}$ relaxation time. However, the sizes of the protein bundles, fat globules, and water pockets found in the cheese are too small to generate sufficiently strong magnetic field gradients to account for more than a minor fraction of the $\mathrm{T}_{2}$ relaxation Kuo (2001). Hills et al. (1989, 1990) demonstrated that chemical exchange between the mobile water and proteins can account for the relaxation behavior of the bulk water in various protein suspensions. Given that cheese can be viewed as a complex protein suspension, chemical exchange appears to be the best model for the data.

Increase in $\mathrm{D}$ values but decrease in $\mathrm{T}_{2}$ values of frozen-stored pasta filata Mozzarella cheese samples 
tempered for $1 \mathrm{~d}$ with respect to unfrozen samples suggest that chemical exchange between different sites of different mobilities was the main mechanisms involved in water relaxation in frozen-stored pasta filata Mozzarella cheese sample tempered for $1 \mathrm{~d}$. Scanning electron microscopy micrographs presented in Kuo (2001) show that stretching during pasta filata Mozzarella cheese making creates a network of parallel-oriented protein fibers, resulting in an uneven distribution of water within the cheese matrix, but the sizes of the structures argue against this being a major contributor to the relaxation of the water. Thus, in pasta filata Mozzarella cheese matrix, the range of $\mathrm{T}_{2}$ values probably represents the number and variety of sites available for chemical exchange. Thus, the distributions of $\mathrm{T}_{2}$ values of unfrozen pasta filata Mozzarella cheese samples were broad (Figures 9A and 10A).

Freezing and frozen storage of pasta filata Mozzarella cheese resulted in the rupture of water retaining protein fibers within discrete locations of the cheese protein matrix (Kuo, 2001). From the NMR viewpoint, local damage to the protein fibers in a cheese sample during freezing and frozen storage should cause an increase in the number and types of sites available for chemical exchange within the damaged regions of the protein matrix. An increase in the number and accessibility of these chemical exchange sites would result in a decrease in the extent of $\mathrm{T}_{2}$ values, thus, leading to a narrow distribution of $\mathrm{T}_{2}$ values in frozen-stored cheese samples tempered for $1 \mathrm{~d}$. According to Kuo et al. (2001), water in pasta filata Mozzarella cheese could be classified into two dominant fractions by $\mathrm{T}_{2}$ relaxation times, a more mobile fraction and a less mobile fraction. Fontecha et al. (1993) reported that freezing cheese causes a high proportion of unordered structure. This might result in exposure of water molecules that are in exchange with proteins of cheese matrix to the bulk water. As the frozen-stored cheese samples thawed, there is an increased number of water molecules in chemical exchange with the protein matrix mixing with more mobile water causing both a narrowing of the $\mathrm{T}_{2}$ distribution and a shift to shorter $\mathrm{T}_{2}$ values (Figures $9 \mathrm{~B}, 9 \mathrm{E}$, and $10 \mathrm{E}$ ).

According to the $\mathrm{D}$ values and $\mathrm{T}_{2}$ relaxation times we determined, the access of the water molecules to the exchangeable protons within the protein matrix might be the dominant mechanism involved in water relaxation of frozen-stored pasta filata Mozzarella cheese sample during the 14-d tempering. For pasta filata Mozzarella cheese stored frozen at $7 \mathrm{~d}$ post-manufacture, tempering the frozen-stored cheese samples shifted the $\mathrm{T}_{2}$ peak to a shorter $\mathrm{T}_{2}$ relaxation time. The $\mathrm{T}_{2}$ values became narrowly distributed compared with the frozen-stored samples tempered for $1 \mathrm{~d}$, since the relocation of water molecules into the proteins of the cheese matrix occurred during tempering as evidence by a decrease in the $\mathrm{D}$ values of frozen-stored sample during tempering. For pasta filata Mozzarella cheese stored frozen at 2-d postmanufacture, tempering the 4-wk frozen-stored cheese samples shifted the $\mathrm{T}_{2}$ peaks to a longer $\mathrm{T}_{2}$ relaxation time. The $\mathrm{T}_{2}$ values became broader than the frozen-stored samples tempered for $1 \mathrm{~d}$. Although changes in the $\mathrm{D}$ values of 4 wk frozen-stored pasta filata Mozzarella cheese during tempering were not systematic, the results of water $\mathrm{T}_{2}$ relaxation alone might indicate that the proteins are unable to fully regain their initial structure as a result of tempering. As the protein regains its structure, it is probable that intramolecular binding prevents the bulk water from gaining access to the exchangeable protons of the protein.

The protein fibers in the cheese matrix of the 4-wk frozen-stored pasta filata Mozzarella cheese samples may be severely damaged when stored frozen at 2-d postmanufacture. This might be due to growth of the ice crystals. Because most of the water molecules in Mozzarella cheese matrix exist in the fat-serum channels at 2-d aging (Oberg et al., 1993; Kuo et al., 2001), there might be an increase in the ice crystal size during freezing and longer frozen storage compared with the cheese samples which stored frozen at 7-d postmanufacture or for shorter period. After thawing, most of the water molecules might be still in the fat-serum channels and only a small part of them might be in contact with the protein matrix during tempering due to the severe damage of the protein fibers in the frozenstored cheese matrix, resulting in broader distribution of water mobility and more mobile water (Figure $9 \mathrm{~F}$ and G). It appears that the protein matrix was not altered significantly as the 7-d aged pasta filata Mozzarella cheese sample stored frozen for $1 \mathrm{wk}$, since the distribution of $\mathrm{T}_{2}$ of the 1-wk frozen-stored cheese sample tempered for $1 \mathrm{~d}$ (Figure 10B) was similar in general appearance to that of the unfrozen sample (Figure 10A).

\section{Non-Pasta Filata Mozzarella}

Figure 11 shows the histogram distribution of $\mathrm{T}_{2}$ values as the non-pasta filata Mozzarella cheese sample stored frozen at 2-d postmanufacture. When the 1-wk frozen stored cheese sample was tempered, the $\mathrm{T}_{2}$ peak at $12 \mathrm{~ms}$ for unfrozen sample (Figure 11A) had shifted to $20 \mathrm{~ms}$, and the distribution of $\mathrm{T}_{2}$ values became wider (Figure 11B). Frozen storage of the cheese sample for $4 \mathrm{wk}$ slightly changed the distribution of $\mathrm{T}_{2}$ values (Figure 11E). As the frozen-stored cheese samples tempered, the peak of the $\mathrm{T}_{2}$ distribu- 

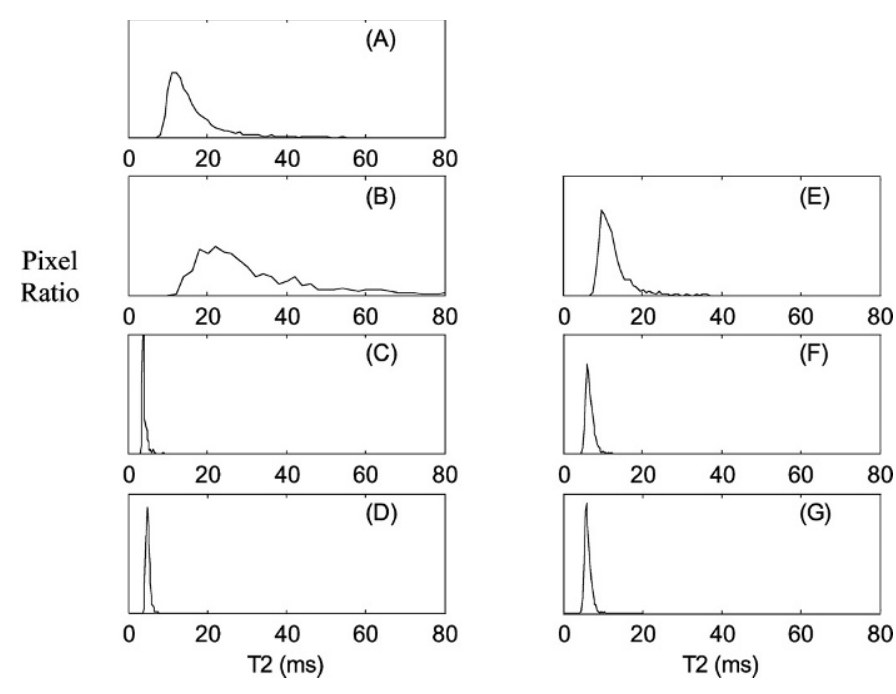

Figure 11. Histogram distribution of $T_{2}$ relaxation time in nonpasta filata Mozzarella cheese unfrozen (A) and frozen $2 \mathrm{~d}$ postmanufacture then thawed after $1 \mathrm{wk}$ and tempered for 1 (B), 7 (C), and $14 \mathrm{~d}(\mathrm{D})$; thawed after $4 \mathrm{wk}$ and tempered for $1(\mathrm{E}), 7(\mathrm{~F})$, and $14 \mathrm{~d}$ (G). Pixel ratio on Y-axis is the number of pixels of a certain range of $\mathrm{T}_{2}$ values divided by total number of pixels in the image.

tion shifted to shorter $T_{2}$ relaxation times and the $T_{2}$ distribution narrowed (Figure 11C, D, F, and G).

The distribution of $\mathrm{T}_{2}$ values as the non-pasta filata Mozzarella stored frozen at 7-d postmanufacture is given in Figure 12. The $\mathrm{T}_{2}$ peak at $6 \mathrm{~ms}$ for the unfrozen cheese sample (Figure 12A) shifted to a longer $\mathrm{T}_{2}$ relax-
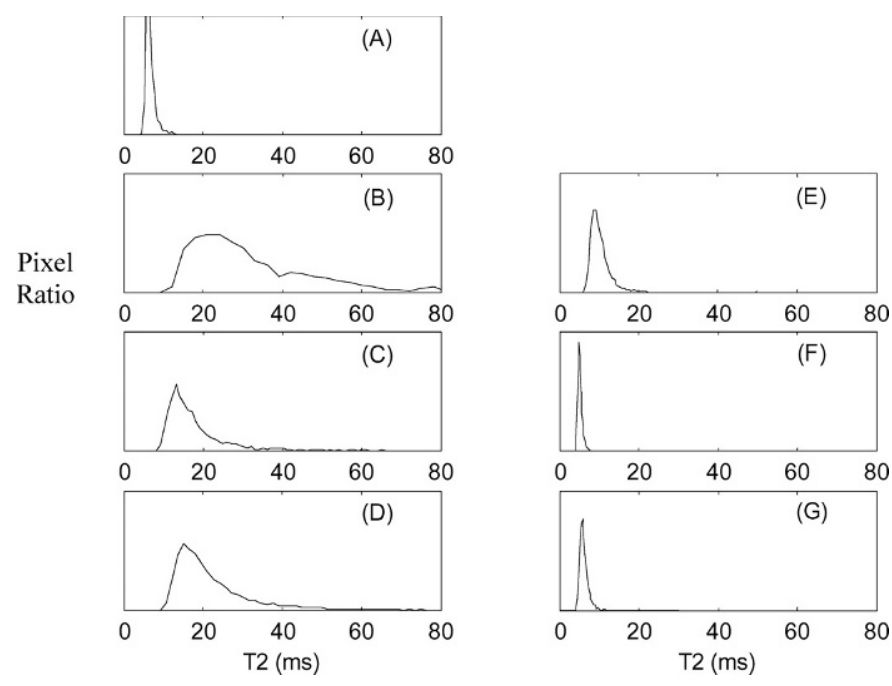

Figure 12. Histogram distribution of $T_{2}$ relaxation time in nonpasta filata Mozzarella cheese unfrozen (A) and frozen $7 \mathrm{~d}$ postmanufacture then thawed after $1 \mathrm{wk}$ and tempered for 1 (B), 7 (C), and $14 \mathrm{~d}(\mathrm{D})$; thawed after $4 \mathrm{wk}$ and tempered for $1(\mathrm{E}), 7(\mathrm{~F})$, and $14 \mathrm{~d}$ (G). Pixel ratio on Y-axis is the number of pixels of a certain range of $\mathrm{T}_{2}$ values divided by total number of pixels in the image. ation time $\left(\mathrm{T}_{2}\right.$ peak at $\left.20 \mathrm{~ms}\right)$ when it was thawed and tempered after 1-wk frozen storage, and the distribution of $\mathrm{T}_{2}$ values became broader (Figure 12B). Tempering the 4-wk frozen-stored cheese sample for $1 \mathrm{~d}$ slightly broadened the peak of $\mathrm{T}_{2}$ distribution (Figure $12 \mathrm{E})$. Tempering the frozen-stored cheese sample up to $14 \mathrm{~d}$ caused the distribution of $\mathrm{T}_{2}$ values to become narrow and the peak of $\mathrm{T}_{2}$ distribution shifted to shorter $\mathrm{T}_{2}$ relaxation times (Figures $12 \mathrm{C}, \mathrm{D}, \mathrm{F}$, and $\mathrm{G}$ ).

During non-pasta filata Mozzarella cheese manufacture, high temperatures are not used, and the fat globules and water pockets are well dispersed within the cheese matrix, thus non-pasta filata Mozzarella cheese is more homogeneous than pasta filata Mozzarella cheese (Kuo et al., 2001; Kuo, 2001). No fiber orientation was evident in the SEM micrographs of non-pasta filata Mozzarella cheese sample (Kuo, 2001). Because the water pockets are small and dispersed evenly within the protein matrix in non-pasta filata Mozzarella cheese sample, the $T_{2}$ values of the cheese samples are more uniform because of similar magnetic environments of those water pockets. Thus, the distributions of $\mathrm{T}_{2}$ values of unfrozen non-pasta filata Mozzarella cheese samples were narrow (Figures 11A and 12A) compared with the pasta filata Mozzarella cheese samples (Figures 9A and 10A).

It appears that non-pasta filata Mozzarella cheese starts with a relatively homogeneous environment for the water protons. The proteins provide a fairly uniform and accessible number of sites for chemical exchange, thus giving the short, narrow ranges of $\mathrm{T}_{2}$ values. Upon freezing, the non-pasta filata Mozzarella cheese loses this homogeneity, resulting in longer $T_{2}$ values. The frozen non-pasta filata Mozzarella may then be more similar to the pasta filata Mozzarella cheese in terms of the magnetic environment experienced by the water. In non-pasta filata Mozzarella cheese, freezing and frozen storage of the samples damaged the protein matrix at localized areas (Kuo, 2001). This damage may result in changes to the protein structure such that the sites for chemical exchange become hidden. Thus, the water pockets experienced fewer opportunities to bind to a protein after thawing the frozen-stored cheese samples; hence, the extent of $\mathrm{T}_{2}$ values increased leading to a broader $\mathrm{T}_{2}$ distribution (Figures 11B, 11E, 12B, and 12E). As frozen-stored cheese samples were tempered for $14 \mathrm{~d}$, most of the protein matrix seemed to recover its ability to exchange with the bulk water causing a shift of $\mathrm{T}_{2}$ peaks to shorter $\mathrm{T}_{2}$ relaxation time and narrowing the distribution of $\mathrm{T}_{2}$ values. Recovery of at least some of the original relaxation profiles is common to both forms of the cheeses. 


\section{CONCLUSIONS}

There was a significant change in the water selfdiffusion coefficient and distribution of $\mathrm{T}_{2}$ relaxation time of water following freezing-thawing, which can be used to characterize effects of freezing on cheeses. The changes in $\mathrm{T}_{2}$, determined spatially at discrete locations within the cheese sample, take into account the localized nature of injury in the frozen-stored cheese sample. For the frozen-stored pasta filata Mozzarella cheese samples tempered for $1 \mathrm{~d}$, the $\mathrm{D}$ values were higher and $\mathrm{T}_{2}$ distributions were narrower than those for the unfrozen samples and with all $\mathrm{T}_{2}$ relaxation times shifting to shorter values. In contrast, the $\mathrm{T}_{2}$ values of the frozen-stored non-pasta filata Mozzarella cheese samples were longer. The differences between $\mathrm{T}_{2}$ distributions of the pasta filata and nonpasta filata Mozzarella cheeses may be attributed to the differences in the cheese microstructure, specifically the ability of the water to exchange with the protein matrix.

Although structural changes in cheese, such as deformation and rupture of the protein matrix, are apparent in SEM micrographs (Kuo, 2001), it is more difficult to quantify and make assessments based on the microstructural features. The quantifiable changes in the NMR parameters may consequently prove more useful. Thus, NMR imaging technique can serve as an alternative tool to assist in the study of changes in cheese quality parameters during frozen storage and/or subsequent thawing.

\section{ACKNOWLEDGMENTS}

This research was founded by a grant from Dairy Management, Inc. (Rosemont, IL). Nuclear magnetic resonance studies were carried out at the National Magnetic Resonance Facility at Madison with support from the NIH Biomedical Technology Program (RR02301) and additional equipment funding from the University of Wisconsin, NSF Academic Infrastructure Program (BIR-9214394), NIH Shared Instrumentation Program (RR02781, RR08438), NIH Research Collaborations to Provide $400 \mathrm{MHz}$ NMR Spectroscopy (GM66326), NSF Biological Instrumentation Program (DMB-8415048), and U.S. Department of Agriculture.

\section{REFERENCES}

Bertola, N. C., A. N. Califano, A. E. Bevilacqua, and N. E. Zaritzky. 1996. Effect of freezing conditions on functional properties of low moisture Mozzarella cheese. J. Dairy Sci. 29:185-190.

Callaghan, P. T. 1990. Susceptibility-limited resolution in nuclear magnetic resonance microscopy. J. Magn. Res. 87:304-318.

Cervantes, M. A., D. B. Lund, and N. F. Olson. 1983. Effects of salt concentration and freezing on Mozzarella cheese texture. J. Dairy Sci. 66:204-213.
Chui, M. M., R. J. Phillips, and M. J. McCarthy. 1995. Measurement of the porous microstructure of hydrogels by nuclear magnetic resonance. J. Colloid Interface Sci. 174:336-344.

Dahlstrom, D. G. 1978. Frozen storage of low moisture, part-skim Mozzarella cheese. M.S. Thesis, Univ. of Wisconsin-Madison, Madison.

Diefes, H. A., S. S. H. Rizvi, and J. A. Bartsch. 1993. Rheological behavior of frozen and thawed low-moisture, part-skim Mozzarella cheese. J. Food Sci. 58:764-769.

Duce, S. L., T. A. Carpenter, and L. D. Hall. 1992. Nuclear magnetic resonance imaging of fresh and frozen courgettes. J. Food Eng. $16: 165-172$.

Fontecha, J., J. Bellanato, and M. Juarez. 1993. Infrared and Raman spectroscopic study of casein in cheese: Effect of freezing and frozen storage. J. Dairy Sci. 76:3303-3309.

Fontecha, J., C. Pelaez, M. Juarez, and M. C. Martin-Hernandez. 1994. Effect of freezing and frozen storage on the physicochemical, organoleptic and microbiological characteristics of a semihard ewes' milk cheese. J. Dairy Res. 61:133-142.

Fontecha, J., M. Kalab, J. A. Medina, C. Pelaez, and M. Juarez. 1996. Effects of freezing and frozen storage on the microstructure and texture of ewe's milk cheese. Z. Lebensm-Unters. Forsch. 203:245-251.

Gamble, G. R. 1994. Non-invasive determination of freezing effects in blueberry fruit tissue by magnetic resonance imaging. J. Food Sci. 59:571-573.

Gasel, J. A., and K. H. Lee. 1974. On the interpretation of water nuclear magnetic resonance relaxation times in heterogeneous systems. J. Am. Chem. Soc. 96:970-978.

Hills, B. 1995. Food processing: An MRI perspective. Trends Food Sci. Technol. 6:111-117.

Hills, B. P., S. F. Takacs, and P. S. Belton. 1989. The effects of proteins on the proton N.M.R. transverse relaxation times of water. I. Native bovine serum albumin. Mol. Physics 67:903-918.

Hills, B. P., S. F. Takacs, and P. S. Belton. 1989. The effects of proteins on the proton N.M.R. transverse relaxation times of water. II. Protein aggregation. Mol. Physics 67:919-937.

Hills, B. P., S. F. Takacs, and P. S. Belton. 1990. A new interpretation of proton NMR relaxation time measurements of water in food. Food Chem. 37:95-111.

Holz, M., and H. Weingartner. 1991. Calibration in accurate spinecho self-diffusion measurements using ${ }^{1} \mathrm{H}$ and less-common nuclei. J. Magn. Reson. 92:115-125.

Kerr, W. L., R. J. Kauten, M. Ozilgen, and M. J. McCarthy. 1996. NMR imaging, calorimetric, and mathematical modeling studies of food freezing. J. Food Process Eng. 19:363-384.

Kerr, W. L., C. J. Clark, M. J. McCarthy, and J. S. de Ropp. 1997. Freezing effects in fruit tissue of kiwifruit observed by magnetic resonance imaging. Sci. Hortic. 69:169-179.

Kerr, W. L., R. J. Kauten, M. J. McCarthy, and D. S. Reid. 1998. Monitoring the formation of ice during food freezing by magnetic resonance imaging. Food Sci. and Technol./Lebensmittel-Wissenchatt Technologie (LWD). 31:215-220.

Kuo, M.-I., S. Gunasekaran, M. Johnson, and C. Chen. 2001. Nuclear magnetic resonance study of water mobility in pasta filata and non-pasta filata Mozzarella. J. Dairy Sci. 84:1950-1958.

Kuo, M.-I. 2001. Distribution and mobility of water in pasta filata and non-pasta filata Mozzarella cheeses. Ph.D. Thesis, Univ. of Wisconsin-Madison.

Kuo, M.-I., and S. Gunasekaran. 2003. Effect of frozen storage on physical properties of pasta filata and non-pasta filata Mozzarella cheeses. J. Dairy Sci. 86:1108-1117.

McCarthy, M. J., and R. J. Kauten. 1990. Magnetic resonance imaging applications in food research. Trends Food Sci. Technol. 1:134-139.

McCarthy, M. J. 1994. Magnetic resonance imaging in food research. Chapman and Hall, New York.

McCarthy, M. J., B. Zion, and P. Chen. 1995 Diamagnetic susceptibility changes in apple tissue after bruising. J. Sci. Food Agric. 67:13-20. 
Oberg, C. J., R. K. Merrill, R. J. Brown, and G. H. Richardson. 1992. Effects of freezing, thawing, and shredding on low moisture, part-skim Mozzarella cheese. J. Dairy Sci. 75:1161-1166.

Oberg, C. J., W. R. McManus, and D. J. McMahon. 1993. Microstructure of Mozzarella cheese during manufacture. Food Struct. $12: 251-258$

Perez-Munuera, I., M. Estevez, and M. A. Lluch. 1999. Note. Study of some typical Spanish cheeses by scanning electron microscopy. Main microstructural modifications caused by freezing. Food Sci. Technol. Int. 5:515-521.

Rutledge, D. N., F. Rene, B. P. Hills, and L. Foucat. 1994. Magnetic resonance imaging studies of the freeze-drying kinetics of potato. J. Food Process Eng. 17:325-352.
Schmidt, S. J., X. Sun, and J. B. Litchfield. 1996. Applications of magnetic resonance imaging in food science. Crit. Rev. Food Sci. Nutr. 36:357-385.

Stejskal, E. O., and J. E. Tanner. 1965. Spin diffusion measurements: spin echoes in the presence of a time dependent field gradient. J. Chem. Phys. 42:288-292.

Tejada, L., E. Sanchez, R. Gomez, M. Vioque, and J. FernandezSalguero. 2002. Effect of freezing and frozen storage on chemical and microbiological characteristics in sheep milk cheese. J. Food Sci. 67:126-129.

Webb, B. H., and W. S. Arbuckle. 1977. Freezing of dairy products. Page 357-395 in Fundamentals of Food Freezing. N. W. Desrosier, ed. AVI Pub. Co., Westport, CT. 